\title{
Introduction to European Pragmatism
}

\section{Giovanni Maddalena and Friedrich Stadler}

\section{(2) OpenEdition}

\section{Journals}

Electronic version

URL: http://journals.openedition.org/ejpap/1481

DOI: 10.4000/ejpap.1481

ISSN: 2036-4091

\section{Publisher}

Associazione Pragma

\section{Electronic reference}

Giovanni Maddalena and Friedrich Stadler, «Introduction to European Pragmatism », European Journal of Pragmatism and American Philosophy [Online], XI-1 | 2019, Online since 19 July 2019, connection on 24 September 2020. URL : http://journals.openedition.org/ejpap/1481 ; DOI : https://doi.org/10.4000/ ejpap. 1481

This text was automatically generated on 24 September 2020 .

\section{c) (i) (8)}

Author retains copyright and grants the European Journal of Pragmatism and American Philosophy right of first publication with the work simultaneously licensed under a Creative Commons AttributionNonCommercial-NoDerivatives 4.0 International License. 


\title{
Introduction to European Pragmatism
}

\author{
Giovanni Maddalena and Friedrich Stadler
}

\section{Introduction}

1 In the past few years, the Vienna Circle Institute has been interested in the issue of ascertaining whether a specifically European Pragmatism existed and in identifying its characteristics as compared to its better-known North American cousin. The Institute organized two conferences to discuss this question: "Logical Empiricism and Pragmatism" in 2013 and "European Pragmatism - Historical and Contemporary Perspectives" in April 2018. The University of Chieti and the University of St. Gallen organized conferences on these topics in 2017 and in 2019, respectively.

2 This issue of the European Journal of Pragmatism and American Philosophy intends to follow and foster this historical and theoretical line of thought in pragmatist studies. In fact, pragmatism can be understood in two ways: more narrowly as a specific school of philosophy, and more broadly as providing perspectives on methods of inquiry, science, and human life. Charles S. Peirce, William James, John Dewey, and George H. Mead understood pragmatism primarily as a distinctive method for addressing logical and philosophical questions, but other proponents of pragmatism found it more important to emphasize its pluralistic nature: in the classical epoch of pragmatism, Arthur O. Lovejoy and Ferdinand C.S. Schiller distinguished between thirteen and seven forms of pragmatism, respectively. After its first generation, the classic tradition of pragmatism entered into a dialogue with other schools of thought, especially those coming from the twentieth-century "neo-positivist" tradition. Despite what they declared, a clear thread unites logical empiricism as it existed in Berlin, Prague, and Vienna with the American movement, both in its classic form and in new forms that were proposed around the middle of the past century by authors like Clarence I. Lewis, Charles W. Morris, and Willard O. Quine. Starting from the late 1970s, neo-pragmatist 
authors began offering a different spin on the classic American movement by fostering an ongoing collaboration with analytic philosophy and other traditions of thought.

This issue, following a historical perspective, intends to identify and reassess the different forms of "European pragmatism" and how they interacted with American pragmatism, above all with the authors of the classic period. This attempt can be seen as the first step of a much broader project that we hope will involve many other researchers. Reasonable starting points for such a comparison on the European side are Ernst Mach, Wilhelm Jerusalem, Eduard Baumgarten, Georg Simmel, Moritz Schlick, Rudolph Carnap, and Frank P. Ramsey. Although critics have traditionally read some of these thinkers as antagonists of pragmatism, recent scholarship has identified many points of contact and even convergences. The papers collected here demonstrate this keener reading of the philosophy of the period. One upshot of this focus is the insight that since the second half of the nineteenth century, lively pragmatic modes of thought and methods have emerged in Europe, in parallel and also interacting with classical American pragmatism - even if this movement was not always presented under the explicit label "pragmatism" by its proponents. This inchoate pragmatism can characterize a first approach to a genuine European philosophizing à la pragmatiste, which has become manifest in many fields. One of these is probability theory, which was one of the focuses of the long-term Research Network Program titled "The Philosophy of Science in a European Perspective" (PSE) sponsored by the European Science Foundation (ESF) that ran from 2008 to 2013, the products of which have appeared in many publications. In this issue one can find an interesting update to this thread of thought related to probability theory.

4 A second approach to European pragmatism is characterized by differences among its national manifestations. European thinkers have read and absorbed classical pragmatism but have developed original forms of it according to the traditions of thought already present in each of their countries, forms that are relevant to understanding European pragmatism as a whole. The present issue contains innovative articles about pragmatism in Italy and Finland, two of the most distinguished forms of European pragmatism. The conclusion that can be drawn from these articles is that despite the fact that many different varieties of pragmatism have been developed, there is still a common project shared by American and European pragmatists. It is expected that future issues will expand the analysis to include pragmatism as it has been developed in England, France, Poland, Spain, and central Europe.

5 In the dual perspective on European pragmatism that the symposium tackles - the dialogue with logical empiricism and the various national forms - it is clear that pragmatism has always involved a common project concerned with a unity between practice and theory and with a serious consideration of the methods and results of modern science, while still giving due attention to a wider philosophical perspective.

6 This symposium introduces the concept of "European pragmatism." It is the hope of the editors that it will inspire future studies comparing the intellectual and philosophical manifestations of pragmatism on the two continents as part of an ongoing transatlantic exchange and enterprise. 


\section{AUTHORS}

GIOVANNI MADDALENA

Università del Molise

maddalena[at]unimol.it

\section{FRIEDRICH STADLER}

Institut Wiener Kreis, Universität Wien

Friedrich.Stadler[at]univie.ac.at 